\title{
Molecular techniques for clinical diagnostic bacteriology
}

\author{
Klinik bakteriyoloji tanısında moleküler teknikler
}

\author{
Nevriye GÖNÜLLÜ1
}

\begin{abstract}
Molecular methods have contributed tremendously to the understanding of the pathogenesis and epidemiology of infectious diseases. The polymerase chain reaction $(P C R)$ is the most widely used target nucleic acid amplification method. By this method, a single copy of a nucleic acid is multiplied to more than 107 times within a very short period. New technologies such as real-time PCR, sequencing and mass spectrophotometry have been described and have many applications in a clinical microbiology laboratory. The greatest impact of real-time assays was in the field of virology where they have been used to detect rapidly a range of viruses in human specimens and to monitor quantitatively viral loads and response to antiviral therapy. In bacteriology they are used for rapid detection of bacterial pathogens and/or antibiotic resistance genes can help to ensure the appropriate use of antibiotics, reduce the duration of hospital stay and minimize the potential for resistant strains of bacteria to emerge. Commercial kits employing PCR technology for detection of Neisseria gonorrhoeae and Chlamydia trachomatis have been developed. Nucleic acid amplification tests can be used directly to identify Mycobacterium tuberculosis complex in clinical specimens. Some clinical laboratories have developed their in-house assays based on PCR assays to detect M. tuberculosis in clinical specimens. Some studies have compared the kits and "in-house" methods and have found similar results. In addition to in-house developed assays, there are commercial amplification tests some of them that are widely used. This chapter describes the basic principles and applications of recently DNA-based molecular techniques for the clinical bacteriology.
\end{abstract}

Key Words: Bacteriology, molecular biology, PCR

\section{ÖZET}

Moleküler yöntemler enfeksiyon hastalıkların patogenezinin ve epidemiyolojisinin anlașılmasında çok önemli katkıda bulunmuştur. Polimeraz zincir reaksiyonu (PZR), en yaygın kullanılan hedef nükleik asit amplifikasyon yöntemidir. Bu yöntem ile tek bir nükleik asidin kopyası çok kısa bir süre içinde 107 kereden fazla çoğalır. Gerçek zamanlı PZR, sekanslama tekniği ve kütle spektrofotometresi gibi yeni teknolojiler klinik mikrobiyoloji laboratuvarında birçok uygulama alanı kazanmıștır. Gerçek zamanlı tekniklerin en büyük etkisi viroloji alanında olmuștur ve bu tekniklerin klinik örneklerde çeșitli virüslerin tespiti, kantitatif viral yükleri ve antiviral tedaviye yanıtı izlemek için kullanılmıștır. Bakteriyoloji alanında bakteriyel patojenler ve/veya antibiyotik direnç genlerinin hızlı tanımlanması, antibiyotiklerin uygun kullanımını sağlar, hastanede kalıș süresini kısaltır ve dirençli sușların gelișme potansiyelini azaltır. Neisseria gonorrhoeae ve Chlamydia trachomatis tespiti için PZR teknolojisi kullanan ticari kitler geliștirilmiștir. Nükleik asit amplifikasyon testleri klinik örneklerde Mycobacterium tuberculosis kompleks'inin doğrudan tespitinde kullanılabilir. Bazı klinik laboratuvarlar, klinik örneklerden $M$. tuberculosis' $i$ tespit etmek için PZR deneylerine dayalı kendi in-house deneylerini geliștirmiștir. Bazı çalıșmalar hazır kitleri ve "in-house" yöntemleri karșılaștırmıștır ve benzer sonuçlar bulmuștur. In-house geliștirilen yöntemlere ek olarak bazı ticari amplifikasyon kitleri yaygın olarak kullanılmaktadır. Bu bölümde güncel DNA yöntemine dayalı moleküler tekniklerin temel ilkelerini ve klinik bakteriyoloji için uygulamaları açıklanmıștır.

Anahtar Kelimeler: Bakteriyoloji, moleküler biyoloji, PZR

İstanbul University, Cerrahpasa Medical Faculty, Department of Medical Microbiology, ISTANBUL, TURKEY

\begin{tabular}{|c|c|c|}
\hline \multicolumn{3}{|c|}{ İletişim / Corresponding Author : Nevriye GÖNÜLLÜ } \\
\hline Istanbul University, Ce & I Faculty, Department of Medical Microbiology, ISTANBUL, TURKEY & Geliş Tarihi / Received : 03.01.2015 \\
\hline Tel : +902124143000 & E-posta / E-mail : ngonullu@istanbul.edu.tr & Kabul Tarihi / Accepted : 26.01.2015 \\
\hline
\end{tabular}

DOI ID : 10.5505/TurkHijyen.2015.32704

Gönüllü N. Molecular techniques for clinical diagnostic bacteriology. Turk Hij Den Biyol Derg, 2015; 72(1): 63-72. 


\section{INTRODUCTION}

Since 1983 many molecular methods have been developed for the detection and genotyping of bacteria. These methods have contributed tremendously to the understanding of the pathogenesis and epidemiology of infectious diseases (1). The molecular methods for diagnostic microbiology are diverse and they can be classified into one of these categories: hybridization, amplification, and sequencing and enzymatic digestion of nucleic acids (2).

\section{Molecular techniques}

\section{Nucleic acid hybridization methods}

Hybridization assays using DNA probes were developed in the early 1960s. DNA probes have been used successfully to identify a wide variety of pathogens from simple viruses to pathogenic bacteria and parazites. Direct diagnosis by nucleic acid probe hybridization is simple, rapid, and relatively free of the contamination and inhibition problems associated with target amplification methods. The sensitivity of probe hybridization methods is limited by the relatively large number of copies ( 104) of the target sequence required to generate a positive signal $(1,3)$.

Specific gene probes have also been developed for the recognize of specific antibiotic resistance genes, so that antimicrobial susceptibility of an infecting organism can be determined directly without primary isolation and growth. Commercial kits incorporating DNA probes are now available to detect a range of bacteria and viruses (4).

\section{Nucleic acid amplification technology}

The polymerase chain reaction (PCR) is the most widely used target nucleic acid amplification method. By this method, a single copy of a nucleic acid is multiplied to more than 107 within a very short period. A thermostable DNA polymerase and two specific oligonucleotide primers are used to produce multiple copies of specific nucleic acid regions during 25 to 50 repetitive cycles $(4,5)$. The method has received particular attention for detecting the presence of low numbers of bacteria or virus particles in clinical and environmental specimens. Commercial kits employing PCR technology for detection of Mycobacterium tuberculosis, Neisseria gonorrhoeae and Chlamydia trachomatis have been developed. Although PCR is the most widely used method, other amplification techniques for DNA and RNA molecules are available (ligase chain reaction, transcriptionmediated amplification, stand displacement amplification). After the amplification reaction has occured, the simplest method to identify the product by size is the electrophoresis and migration on an agarose gel (4-6).

\section{Real-time amplification}

Most conventional PCR-based tests require multiple manipulations and the PCR products are detected in a separate gel electrophoresis system. Compared with conventional PCR, real-time PCR is faster and contamination risk is reduced. It detects amplified target by fluorescently labeled probes as the hybrids are formed (i.e., detection of amplicon in real time). The signal produced is related to the amount of amplicon present at the end of each cycle and increases as the amount of specific amplicon increases $(4,5,7)$. Commercially available robotic nucleic acid extraction systems, combined with rapid thermal cyclers and instrumentation (e.g. LightCycler, TaqMan $\odot$ ) capable of detecting and differentiating multiple amplicons, make real-time PCR an attractive and viable proposition for the routine diagnostic laboratory. Real-time assays have been extremely useful for studying microbial agents of infectious disease. The greatest impact to date has been in the field of virology where, real-time assays have been used to detect rapidly a range of viruses in human specimens and to monitor quantitatively viral loads and response to antiviral therapy. Benefits 
to the patient can also be seen in bacteriology, where rapid detection of bacterial pathogens and/ or antibiotic resistance genes can help to ensure the appropriate use of antibiotics, reduce the duration of hospital stay and minimize the potential for resistant strains of bacteria to emerge. Recent developments in real-time PCR have suggested a future in which rapid identification, quantification and typing of a range of microbial targets in single multiplex reactions will become commonplace $(8,9)$.

\section{Molecular typing of microorganisms}

Molecular typing of microorganisms are useful in the investigation of epidemiological relationships during infectious outbreaks, in determining routes and sources of infections and epidemiological surveillance of infectios diseases. Molecular fingerprinting methods are being used increasingly to distinguish clinical isolates and for assessing the reladness of individual bacterial isolates in epidemiological studies $(4,10)$.

Pulsed-field gel electrophoresis (PFGE) is now recognized as the gold stardard molecular technique used to examine the molecular relatedness of bacteria. The principle of PFGE is to use a specialized electrophoresis apparatus to separate chromosomal fragments produced by enzymatic digestion of bacterial DNA (11).

\section{Mass Spectrometry}

Mass spectrometry is an analytical technique with high specificity used for determining the elemental composition of samples, quantifying the mass of particles and molecules, and elucidating the chemical structure of molecules. For example, MALDI-TOF MS, are being increasingly valued and utilized as tools in clinical microbiology laboratories (12).

\section{Bacterial infections}

\section{C. trachomatis and N. gonorrhoeae}

C. trachomatis and $N$. gonorrhoeae infections are among the most frequently sexually transmitted infections in the world. These infections (associated with syphilis and lymphogranuloma venereum) are constantly increasing since the 2000s (13). A study in the United States showed that about $4.1 \%$ of the young population aged 18-26 were infected with C. trachomatis and $0.43 \%$ with $N$. gonorrhoeae (14). In France, the prevalence is higher with a range between $10 \%$ and $18 \%$ and the most affected population are young people aged between 15-30 $(15,16)$. Both infections have an important clinical polymorphism and can affect the uterus, the urethra, rectum, oropharynx and the conjunctiva. These infections are often asymptomatic ( $50 \%$ of cases for $C$. trachomatis). They can be in the form of urethritis or cervicitis. In women, these infections can reach the genital area and cause pelvic inflammatory disease, endometritis or salpingitis and lead to infertility or ectopic pregnancy. In man, these two bacteria cause urethritis which can progress to chronic epididymitis that can cause infertility. In both sexes, gonorrhoeae can progress to arthritis, meningitis or endocarditis (17). Reiter syndrome (urethritis, conjunctivitis, polyarthritis and mucocutaneous lesions) can be initiated by genital infections with $C$. trachomatis (18). In addition, some strains of $C$. trachomatis (serovars L1, L2, L2a, L2b and L3) are responsible from a rare disease, lymphogranuloma venereum. Its prevalence increases significantly in recent years and causes genital ulcerative lesions, lymphadenitis, proctitis, rectal fistulas and draining sinuses progressing to chronicity. Perinatal infections are also possible for $C$. trachomatis and $N$. gonorrhoeae. Approximately one fourth to half of infants born to women infected with $C$. trachomatis develop conjunctivitis and about $10 \%$ to $20 \%$ of infants develop pneumonia. $N$. gonorrhoeae can produce a severe conjunctivitis (ophtalmia neonatorum) or sepsis. All these elements show the importance of early detection of these infections (15).

\section{C. trachomatis and molecular biology}

C. trachomatis is an obligate intracellular bacteria organism which culture is difficult (19). Previously considered the gold standard (restricted to a few specialized laboratories), this technique is time consuming (results in three-seven days) and 
expensive. Culture is highly specific $(100 \%)$ but is relatively insensitive (40-85\%). The sensitivity of culture is compromised if inadequate specimens are used and if viability of bacteria has been lost during transport of the specimen (18). Antigen detection methods are commercialy available: direct fluorescent antibody (DFA) with fluoresceinconjugated monoclonal antibodies and enzymelinked immunosorbent assay (ELISA). The sensitivity of each test has been reported to vary enormously and neither is found as sensitive as culture or nucleic acid-based tests. Antibody detection with serology is of limited value in the diagnosis of urogenital infections in adults because it cannot differentiate between current and past infection. Serology can be used to diagnose lenfogranuloma venereum $(5,18)$.

Nucleic Acid-Based tests are nucleic acid hybridization tests that measure the presence of species-specific sequence of $16 \mathrm{~S}$ ribosomal RNA ( $r R N A$ ). These tests are rapid and relatively inexpensive; however they are more reliable in patients who are symptomatic and shedding large numbers of bacteria than those who are asymptomatic and most likely shedding fewer bacteria (18).

Nucleic acid amplification tests (NAATs) are polymerase chain reaction (PCR), ligase chain reaction, standard displacement amplification and transcription-mediated amplification. Most comparative studies indicate that these tests are more sensitive than culture and nonnucleic acid amplification assays $(5,20,21)$. First-voided urine specimens from men and women are acceptable specimens. Care must be taken to monitor for the presence of inhibitors. Despite this inconvenient, nucleic acid amplification tests are currently the most preferred tests for the laboratory diagnosis of genital C. trachomatis infection (18). Table 1 summarizes the various molecular tests used in the diagnosis of C. trachomatis and $N$. gonorrhoeae infections.

\section{N. gonorrhoeae and molecular biology}

$N$. gonorrhoeae is an intracellular organism which unlike $C$. trachomatis can be easily cultured.
The specificity (100\%) and sensitivity of this technique (85\%) are excellent. The result is obtained in one to three days. In addition, susceptibility test can be performed (25). For some authors, in areas where the $N$. gonorrhoeae prevalence is low, the culture is preferred over testing gene amplification (22). Other authors did not observe differences in sensitivity and specificity kits depending on the prevalence (23).

\section{The molecular biology tests (C. trachomatis} and $N$. gonorrhoeae)

Molecular biology tests using probe hybridization are also used for direct detection of $N$. gonorrhoeae. The PACE 2 DNA probe assay (Gen-Probe, San Diego, (A) is a nonisotopic chemiluminescent DNA probe system for direct detection of gonococcal ribosomal RNA in genital and conjunctival specimens. The sensitivities of this test have ranged from $85.5 \%$ to $100 \%$ for femal endocervical specimens and 91.5 to $100 \%$ for male urethral specimens (24). However, tests using amplification techniques are preferred and used routinely (17)(Table 1).

Table 1. Principals commercial kits for the detection of Chlamydia trachomatis and Neisseria gonorrhoeae infections

\begin{tabular}{ll}
\hline Kit & Company \\
\hline Detection after amplification: & \\
(Cobas) Amplicor CT/NG (PCR) & Roche \\
(Cobas) TaqMan CT (real-timePCR) & Roche \\
AMPLIFIED (only CT) (NASBA) & BioMérieux \\
APTIMA COMBO 2 (TMA et HPA) (CT or NG) & Gen-Probe \\
BD ProbeTec CT/NG (SDA) & Becton-Dickinson \\
Hybrid Capture CT/GC & Digene \\
RealArt artus (real-time PCR) & Qiagen \\
Direct detection in clinical specimens: & \\
\hline Pace 2 (only for CT or NG) (HPA) & Gen-Probe \\
\hline $\begin{array}{l}\text { Detection from culture: } \\
\text { Accuprobe NG (HPA) }\end{array}$ & \\
Isolated or combined detection (CT and NG) & Digene \\
CT ID, GC ID, CT/GC Hybrid Capture 2 & \\
\hline
\end{tabular}


The amplification tests are achievable in urine, urethral, endocervical or vaginal. According to the biological origin of the sample, specificity and sensitivity of the tests vary (25). For example, for C. trachomatis, the Amplicor ${ }^{\mathrm{T}} \mathrm{kit}$ ( Roche) has a sensitivity ranging from 45 to $80 \%$ in women, of $92 \%$ in men in the urine and $98 \%$ in the urethral level. For $N$. gonorrhoeae, the Amplicor kit has a sensitivity of $84-100 \%$ for endocervical, $100 \%$ for the urethra, $67 \%$ for urine in women and $95 \%$ for the urine in man. Some authors reported that the search for $C$. trachomatis (and not N. gonorrhoeae) in urine has the same sensitivity and specificity in men as than in women with that of urethral or cervicovaginal samples (23). In addition, these kits whatever technical amplification used are equivalent in terms of the sensitivity specificity $(23,25)$. However, gene amplification tests may not differentiate a living from a dead organism. Therefore, there is not recommended to do this research if the individual has followed a specific treatment (antibiotics particular) in the previous three weeks. In addition, in areas with low prevalence, in the case of a positive amplification test results, some authors recommend to perform a second confirmatory test (to eliminate false positives) on the same sample or to prelevate a new sample for the culture $(26,27)$.

\section{Tuberculosis}

\section{Detection of M. tuberculosis}

The World Health Organization (WHO) estimates that the global tuberculosis epidemic results in about 9 million new cases and in 2 million deaths annually. Approximately one third of the world population is infected with $M$. tuberculosis. Regions with the highest incidence of disease are particularly countries with limited medical resourses. In the other hand it still remains a major problem in industrialized countries. In these countries, socioeconomic factors such as immigration, the homeless, drug and alcohol abuse and people infected with the human immunodeficiency virus (HIV) are recognized as the most important reasons of the resurgence of tuberculosis. Because it is difficult to eradicate disease in these patients, spread of this infection to other populations poses an important public health problem (18). The early diagnosis and adequate treatment of infectious patients with pulmonary tuberculosis are very important to reduce transmission of M. tuberculosis and to achieve the disease elimination (28).

It has been estimated that when using standard concentrating techniques, approximately 10000 acidfast bacilli per milliliter of sputum are required to be detected by routine microscopy (staining with auramine or Ziehl-Nielsen) $(29,30)$. This test cannot identify the particular mycobacterial species. On the other hand, a positive acid-fast stain reaction corresponds to higher activity (18).

Culture is considered the reference (gold standard) method to confirm the diagnosis. Unfortunately, it generally took 4 to 8 weeks for $M$. tuberculosis and other important slow-growing bacteria to grow on the Lövenstein-Jensen media. However, this time has been shortened through the use of specially formulated broth cultures the rapid growth of most mycobacteria. Thus the average time to grow mycobacteria in these automated detection systems (e.g., BacT / ALERT ${ }^{T M}$ or system BACTEC ${ }^{\mathrm{T} M}$ systems) has been decreased to approximately 12 to 14 days. In addition, sputum or bronchoalveolar lavage requires prior decontamination with $\mathrm{N}$-acetyl-L-cysteine and sodium, which can cause a significant decrease in the number of bacteria. Other methods such as to gas chromatography-mass spectrometry or ELISA did not improve the detection (31).

Thereafter, the need of new rapid and accurate diagnostic methods has emerged. For this reason, techniques have been developed to detect specific mycobacterial nucleic acid sequences present in clinical specimens in order to achieve higher sensitivity and specificity compared to traditional methods of microscopic examination and culture $(18,28)$.

Nucleic acid amplification tests (e.g., polymerase chain reaction-PCR) can be used directly on clinical specimens (sputum). These tests amplify target 
nucleic acid regions in viable or nonviable bacilli, which uniquely identify $M$. tuberculosis complex. Some clinical laboratories have developed their in-house assays based on PCR assays to detect M. tuberculosis in clinical specimens and commercial kits. Some studies have compared the kits and "in-house" methods and have found similar results (32). In addition to in-house developed assays, there are commercial amplification tests some of them that are widely used: Amplicor MTB test (Roche diagnostics System) and the Amplified Mycobacterial Tuberculosis Direct test (Gen Probe, Inc San Diego). Table 2 summarize some test kits and Table 3 summarize the sensitivity and the specifity of these amplification tests used in the diagnosis of $M$. tuberculosis from respiratory samples compared to the culture $(17,33)$. These tests are highly sensitive and specific with acid-fast smear-positive specimen but they are relatively insensitive in smear-negative specimens. The nucleic acids amplification test results must always be confirmed by sputum culture for pulmonary tuberculosis infection. It is also worth to mention that nucleic acid amplification tests have low specificity and sensitivity for extrapulmonary tuberculosis. Because of these limitations current literature evidence suggest that nucleic acid amplification tests cannot replace sputum microscopy and culture in tuberculosis diagnosis and that nucleic acid amplification tests cannot be used in the evaluation of treatment effectiveness in patients receiving therapy $(28,30)$.

Some of the potencial problems of the nucleicacid-based amplification assays are inhibition of amplification by inhibitors that are present in specimens and reporting of false-negative results may be a problem with PCR. For this reason, the use of an internal amplification and the monitoring of the false-negative rate is required (e.g., inhibitors of polymerase in $4 \%$ in the respiratory specimens and $18 \%$ of extrapulmonary samples). In addition, false positives (not related to contamination) can be reported as a result of nonviable mycobacteria DNA remained after treatment tuberculosis $(32,33)$.
Table 2. Principals commercial kits for the detection of M. tuberculosis infections

\begin{tabular}{|c|c|}
\hline Kit & Company \\
\hline $\begin{array}{l}\text { Detection after amplification } \\
\text { Cobas Aplicor M. avium (PCR) } \\
\text { Cobas Amplicor M. intracellulare (PCR) } \\
\text { AMPLIFIED (complexe MT) (TMA and HPA) }\end{array}$ & $\begin{array}{l}\text { Roche } \\
\text { BioMérieux }\end{array}$ \\
\hline $\begin{array}{l}\text { Detection after amplification: } \\
\text { Genotype Mycobacteria Direct (NASBA } \\
\text { and reverse dot-blot) (M. avium, } \\
\text { M. intracellulare, M. kansasii, } \\
\text { M. maloense, M. tuberculosis complex) } \\
\text { RealArt artus (M. tuberculosis complex) }\end{array}$ & $\begin{array}{l}\text { Hain } \\
\text { Lifescience }\end{array}$ \\
\hline $\begin{array}{l}\text { Direct detection in clinical specimens: } \\
\text { Genotype }{ }^{\circledR} \text { MTB Direct v3.0 (reverse } \\
\text { dot-blot) (M. avium, M. intracellulare, } \\
\text { M. kansasii, M. maloense, } \\
\text { M. tuberculosis complex) }\end{array}$ & Biocentric \\
\hline $\begin{array}{l}\text { Detection from culture: } \\
\text { AccuProbe (HPA) Many mycobacteria } \\
\text { (M. avium, M. intracellulare, } \\
\text { M. gordonae, M. kansasii) } \\
\text { AccuProbe (complexe MT) (HPA) }\end{array}$ & Gen-Probe \\
\hline
\end{tabular}

Inno-LiPA Mycobacteria (Reverse dot-blot) Innogenetics

(M. tuberculosis complex,

M. kansasii, M. xenopi, M. gordonae,

$M$. genovense, $M$. simiae, M. marinum

and $M$. ulcerans, M. celatum,

MAIS, M. avium, M. intracellulare,

M. scrofulaceum, M. malmoense,

M. haemophilum, M. chelonae

complex, M. fortuitum complex, and

M. smegmatis)

Genotype ${ }^{\circ}$ Mycobacterium MTBC (Reverse Biocentric dot-blot) Complex Mycobacterium

tuberculosis

Genotype $₫$ Mycobacterium CM/AS

(Reverse dot-blot) Identification of 26

Mycobacteria (M. avium, M. chelonae,

M. abscessus, M. fortuitum,

M. gordonae, M. intracellulare,

M. scrofulaceum, M. interjectum,

M. kansasii, M. malmoense,

M. peregrinum, M. marinum/

M. ulcerans, Complexe

M. tuberculosis, M. xenopi, M. simiae,

M. mucogenicum, M. goodii, M. celatum,

M. smegmatis, $M$. genovense,

M. lentiflavum, M. heckeshornense,

M. szulgai/ M. intermedium, M. phlei,

M. haemophilum, M. kansasii,

M. ulcerans, M. gastri, M. asiaticum,

M. shimoidei)

Genotype ${ }^{\circledR}$ MTBDR (Reverse dot-blot) Hain Resistance detection for isoniazide and Lifescience rifampicin of Mycobacterium tuberculosis 
Identification of mycobacteria in culture

The genus Mycobacteria consist of diverses acid-fast bacilli. The conventional methods for the identification of these organisms are well established bu they are also time consuming and labor intensive. On the other hand, the results of these conventional tests can be sometimes inconclusive. The introduction of species-specific molecular probes have revolutionized the identification of mycobacteria as the most useful means of identifying commonly isolated mycobacteria (e.g., M. tuberculosis, Mycobacterium avium, Mycobacterium kansasii). Because many organisms are present in the culture at the time of initial detection, it is not necessary to amplify the target genomic sequence. The commercially prepared probe identification systems currently used are rapid (test time 2 hours), sensitive and specific $(5,18)$.

\section{Moleculer biology and detection of antimicrobial resistance \\ Mutations leading to rifampicin resistance, a} marker for multidrug-resistant strains have been detected using molecular methods. Many different genotypic assays are currently available for drug susceptibility testing. Most are based on PCR amplification of a specific region of a gene followed by analysis for specific mutations associated with drug resistance. DNA probe assays have also been used to detect rifampin resistance $(5,34,35)$. One of these assays, the INNO-Lipa Rif.TB (Innogenetics NV, Chem, Belgium) is a commercially available reverse hybridization-based probe assay for rapid detection of rifampin mutations leading to rifampicin resistance in M. tuberculosis. The assay has a sensitivity of $80 \%$

Table 3. Sensibility and specifity of amplification tests used in the diagnosis of $M$. tuberculosis isolated from respiratory samples compared to the culture

\begin{tabular}{lccc}
\hline & \multicolumn{2}{c}{ Sensibility $\%$} & \multirow{2}{*}{$\begin{array}{c}\text { Specificity } \\
\%\end{array}$} \\
\cline { 2 - 3 } & M+ & M- & \\
\hline AMTDB (GenProbe) & $90-100$ & $63.6-100$ & $92.1-100$ \\
Amplicor (Roche) & $87.5-100$ & $50-71.7$ & $91.3-100$ \\
BD Probe Tec & $90-100$ & $40.3-100$ & $96-99.8$ \\
RealTime PCR & 99.5 & 52 & 98.3 \\
Lamp test & 97.7 & 48.8 & 99
\end{tabular}

to $100 \%$ for detecting rifampin resistance (36). The second line-probe assay is the Genotype MTBDRplus assay (Hain Lifescience, GmbH, Nehren, Germany) $(34,37)$. The Genotype MTBDRplus assay shows a diagnostic sensitivity of approximately $98 \%$ with a specificity of approximately $99 \%$ for detecting rifampin resistance. For detecting isoniazid resistance the diagnostic sensitivity is approximately $84 \%$ with about the same specificity (approximately 100\%) (38).

\section{Epidemiological surveys}

Molecular techniques permit strains analysis of $M$. tuberculosis isolates for purposes of epidemiologic studies. The most used technique is the RFLP-PCR of the insertion sequence IS6110. The IS6110, was specifically identified as the target of a DNA probe to be used in fingerprint analysis $(30,39)$. Straintyping methods have also been used in the detection of drug-resistant strains of $M$. tuberculosis. There have been developed methods to detect mutations in the M. tuberculosis RNA polymerase (rpoB) to detect mutations associated with rifampin resistance $(30,40)$.

\section{Other bacteria}

Although many amplification techniques exist, the most widely used target nucleic acid amplification method is the polymerase chain reaction (PCR). Table 4 summarize some test kits used in molecular diagnosis of other bacteria than $C$. trachomatis, $N$. gonorrhoae and $M$. tuberculosis (17); Table 5 resumes some bacteria detected by real Time PCR.

The advantage of PCR compared to usual bacterial culture was clearly demonstrated in the following situations:

- Detection and identification of bacteria difficult to grow in culture that are extremely difficult to grow (Bartonella spp., Coxiella burnetii, Borrelia burgdorferi, Ehrlichia spp., Francisella tularensis, Mycoplasma spp., Tropheryma whippelii)

- More rapid detection and identification of bacteria containing mycolic acids that grow slowly (e.g., mycobacteria); more rapid detection of opportunistic bacteria (Legionella spp.). 
- Ability to detect bacteria previously detected by serology (e.g., group A beta-hemolytic streptococci or toxin of Escherichia coli 0157:H7). Quantification of infectious agent burden was proposed for some bacteria to appreciate their role in pathogenesis of diseases (e.g., Streptococcus pneumoniae, methicillinresistant Staphylococcus aureus (MRSA) (41).
- Detection of bacteria in cerebrospinal fluids in the clinical suspicion of meningitis (Neisseria meningitis, S. pneumoniae and Haemophilus influenzae).

- Ability to show nonviable microorganisms that cannot be detected in culture because of other reasons (e.g., a previous antibiotic therapy).

Table 4. Principals commercial kits for the detection of other bacteria

\begin{tabular}{ll}
\hline Kit & Company \\
\hline Bacterial identification: & \\
Sequencing of bacterial regions & Lifescience \\
Microseq & Biotage \\
PyroMark &
\end{tabular}

Detection from culture

Accuprobe (HPA) (Staphylococcus aureus, Streptococcus pneumoniae, Streptococcus group A and Gen-Probe B, Enterococcus, Campylobacter, Haemophilus influenzae)

PNA FISH Staphylococcus aureus (FISH)

PNA FISH Enterococcus faecalis (FISH)

AdvanDX

Gamme Genotype $\circledR$ EHEC: Detection and identification of enterohemorrhagic Escherichia coli Biocentric (EHEC)

Enterococcus: Genetic identification of enterococci and resistance to vancomycin

Blood Culture: Identification of Gram + and Gram- bacteria from blood cultures

Staphylococci: Identification of staphylococci, mecA gene and PVL gene

MicrolDent: Detection and genetic identification of anaerobic periodontal bacteria

Direct detection in clinical specimens:

GASDirect (HPA): Streptococcus group A

Gen-Probe

BD Affirm VPIII Microbial Identification Test: Direct identification of bacteria that cause vaginites Becton-Dickinson

(Candida sp., Gardnerella vaginalis and Trichomonas vaginalis) (DNA hybridization probe)

Test IDI-Strep B (Streptococcus B-Direct Hybridation)

Test IDI-MRSA (Detection of methicillin resistance of Staphylococcus aureus-Direct hybridization)

SepCheck (FISH in whole blood) (Staphylococcus aureus, Coagulase negative Staphylococcus,

Streptococcus spp., Enterococcus faecium and Enterococcus faecalis, Escherichia coli,

Pseudomonas aeruginosa and Enterobacterium spp)

TOCScan (Quantification of bacteria-Real-time PCR SYBR-Green)

Genotype ${ }^{\circledR}$ MRSA Direct (reverse dot-blot): methicillin-resistant Staphylococcus aureus direct Biocentric detection

\section{Bacterial detection:}

Pseudomonas aeruginosa

GeneOhm Science

RiboTechnologies/

Microscreen

Enterococcus faecalis

Staphylococcus aureus and coagulase negative staphylococci

Detection of resistance to therapy:

Detection of methicillin resistance of Staphylococcus spp. (MecA)

Detection of vancomycine resistance (vanA/vanB) of Enterococcus sp.

Gamme RealArt artus (Real-time PCR):

Borrelia spp.

Campylobacter spp.

Listeria monocytogenes spp.

Qiagen

Gamme LightCycler (Real-time PCR):

Candida albicans detection

Detection in whole blood (Real-time PCR):

Aspergillus Tracer: Aspergillus spp. detection

Multiplex assays

Roche

Roche 
- PCR can be used to detect antimicrobial resistance mechanisms (e.g., mecA gene which encodes resistance among methicillin-resistant S. aureus strains, van genes which encode vancomycin resistance among vancomycinresistant enterococci). Phenotypic mehods for resistance detection are stil the methods of choice for most resistance mechanisms determinants because of their simplicity. However, the complexity of emerging resistance mechanisms chalenges the ability and utility of these classic methods $(5,7)$. Unfortunately, there are some limitations in the use of molecular methods for the detection of resistance mechanisms. Despite these important advantages, disadvantages still exist, notably inhibitors (e.g., sputum, urine, feces).
As medical research of infectious diseases evolves, it is hoped that these techniques may also be routinely used to investigate host immunogenetic factors and host susceptibility for particular types of infections. Better understanding of pathogen genomics will lead to the discovery of new diagnostic methods and therapies in the future.

Table 5. Bacteria which can be detected by Real-time PCR

\begin{tabular}{ll}
\hline Bacteria & \\
\hline Group A and B Streptococcus spp. & Mycoplasma pneumoniae \\
Escherichia coli 0157:H7 & Legionella pneumophila \\
Bartonella henselae & Haemophilus influenzae \\
Bartonella pertussis & Neisseria meningitidis \\
Ehrlichia chaffensis & Borrelia burgdorferi \\
Tropheryma whipplei & Bacillus anthracis \\
Yersinia pestis & Clostridium difficile
\end{tabular}

\section{REFERENCES}

1. Phaller MA, Caliendo AM, Versalovic J. Molecular biology. In: Isenberg HD, Garcia LS, eds. Clinical Microbiology Procedures Handbook. Whashington DC. ASM Press, 2007.

2. Lamoril J, Bogard M, Ameziane N, Deybach JC, Bouizegarène P. Molecular biology in clinical microbiology in 2007-Part 1. Immuno-Anal Biol Spec, 2007; 22 (1): 5-18.

3. Nolte FS, Caliendo AM. Molecular microbiology. Manuel of Clinical Microbiology, Washington DC: ASM Pres, No: 10, 2011; 27-59.

4. Greenwood D, Slack R, Peutherer J, Barer M. Medical Microbiology. 17th ed. Philadelphia: Churchill Livingstone, 2007.

5. Forbes BA, Sahm DF, Weissfeld AS. Bailey \& Scott's Diagnostic Microbiology. 12th ed. Philadelphia: Mosby Inc, 2007.

6. Chen SC, Kontoyiannis DP. New molecular and surrogate biomarker-based tests in the diagnosis of bacterial and fungal infection in febrile neutropenic patients. Curr Opin Infect Dis, 2010; 23 (6): 567-77.

7. Cai HY, Archambault M, Gyles CL, Prescott JF. Molecular genetics methods in the veterinary clinical bacteriology laboratory: current usage and future applications. Anim Health Res Rev, 2003; 4 (2): 73-93.

8. Drancourt M. Molecular identification of bacteria. Med Mal Infect, 1998; 28 (4): 380-2.
9. Marcadé G. Rapid diagnostic tests for bacterial infections. Immuno-Anal Biol Spec, 2013; 28 (4): 167-73.

10. Sibley CD, Peirano G, Church DL. Molecular methods for pathogen and microbial community detection and characterization: current and potential application in diagnostic microbiology. Infect Genet Evol, 2012; 12 (3): 505-21.

11. Biron $M$, Berche $P$, Ferroni A. Contribution of the laboratory to the epidemiologic study of bacterial infections. Pathol Biol, 2001; 49 (2): 128-37.

12. Meng $\mathrm{QH}$. Mass Spectrometry applications in clinical diagnostics. J Clinic Experiment Pathol, 2013. S6: e001. doi:10.4172/2161-0681.S6-e001.

13. Herida M, Michel A, Goulet V, Janier M, Sednaoui $P$, Dupin $N$, et al. Epidemiology of sexually transmitted infections in France. Med Mal Infect, 2005; 3 (5): 281-9.

14. Miller WC, Ford CA, Morris M, Handcock MS, Schmitz $\mathrm{JL}$, Hobbs MM, et al. Prevalence of chlamydial and gonococcal infections among young adults in United States. JAMA, 2004; 291 (18): 2229-36.

15. Anaes - Haute Autorité de Santé. Ếvaluation du depistage des infection urogénitales basses à Chlamydia trachomatis en France. Rapport 2003. http://www.has-sante.fr/portail/upload/docs/ application/pdf/Chlamydia_tome2_synth.pdf. Erișim: 02.01.2015 
16. Anaes - Haute Autorité de Santé. Place des techniques de biologie moléculaire dans l'identification des infections urogénitales basses à Chlamydia trachomatis. Rapport; 2003. http://www. has-sante.fr/portail/upload/docs/ application/pdf/Chlamydia_tome1_synth.pdf. Erișim: 02.01.2015

17. Lamoril J, Bogard M, Ameziane N, Deybach JC, Bouizegarène $\mathrm{P}$. Molecular biology in clinical microbiology in 2007-Part 2. Immuno-Anal Biologie Spec, 2007; 22 (2): 73-94.

18. Murray PR, Rosenthal KS, Pfaller, MA. Medical Microbiology. 7th ed. Philadelphia: Saunders, 2013.

19. Hamdad F, Orfila J, Boulanger JC, Eb F. Chlamydia trachomatis urogenital infections in women. Best diagnostic approaches. Gynecol Obstet Fertil, 2004; 32(12): 1064-74.

20. Gaydos CA, Roblin PM, Hammerschlag MR, Hyman CL, Eiden JJ, Schachter J, et al. Diagnostic utility of PCR-enzyme immunoassay, culture, and serology for detection of Chlamydia pneumoniae in symptomatic and asymptomatic patients. J Clin Microbiol, 1994; 32 (4): 903-5.

21. Johnson RE, Green TA, Schachter J, Jones RB, Hook EW III, Black CM, et al. Evaluation of nucleic acid amplification tests as reference tests for Chlamydia trachomatis infections in asymptomatic men. J Clin Microbiol, 2000; 38 (12): 4382-6.

22. Diemert $\mathrm{D}$, Libman MD, Lebel P. Confirmation by 16S rRNA PCR of the cobas amplicor CT/NG test for diagnosis of Neisseria gonorrhoeae infection in a low-prevalence population. J Clin Microbiol, 2002; 40 (11): 4056-9.

23. Cook RL, Hutchinson SL, Ostergaard L, Braithwaite RS, Ness RB. Systematic review: noninvasive testing for Chlamydia trachomatis and Neisseria gonorrhoeae. Ann Intern Med, 2005; 142 (11): 914-25.

24. Mushahwar IK, McGrath LC, Drnec J, Overby LR. Radioimmunoassay for detection of hepatitis B $\mathrm{e}$ antigen and its antibody. Results of clinical evaluation. Am J Clin Pathol, 1981; 76 (5): 692-7.

25. Olshen E, Shrier LA. Diagnostic tests for chlamydial and gonorrheal infections. Semin Pediatr Infect Dis, 2005; 16 (3): 192-8.

26. Anonymous. CDC (Center for Disease Control). Screening tests to detect Chlamydia trachomatis and Neisseria gonorrhoeae infections-2002. morbidity and mortality weekly report 2002; 51. http:// www.cdc.gov/std/labguidelines. Erişim: 02.01.2015

27. Koeck JL, Chakour M, Teyssou R. Apport de la biologie moléculaire au diagnostic bactériologique. Rev Franc Lab, 2001; 2001 (335): 37-41.

28. Tsara V, Serasli E, Christaki P. Problems in diagnosis and treatment of tuberculosis infection. Hippokratia, 2009; 13 (1): 20-2.

29. Heifets L. Gen-Probe test should not be considered final in Mycobacterium tuberculosis identification. J Clin Microbiol, 1989; 27 (1): 229.
30. Winn WJR, Allen S, Janda W, Koneman E, Procop $G$, Schreckenberger P, et al. Koneman's Color Atlas and Textbook of Diagnostic Microbiology. 6th ed. Philadelphia: Lippincott Williams \& Wilkins, 2006.

31. Nahid P, Pai M, Hopewell PC. Advances in the diagnosis and treatment of tuberculosis. Proc Am Thorac Soc, 2006; 3 (1): 103-10.

32. Cheng VC, Yam WC, Hung IF, Woo PC, Lau SK, Tang $\mathrm{BS}$, et al. Clinical evaluation of the polymerase chain reaction for the rapid diagnosis of tuberculosis. J Clin Pathol, 2004; 57 (3): 281-5.

33. Truffot-Pernot C, Veziris N. Bacteriological tests for tuberculosis: standards and perspectives. Rev Mal Res, 2011; 28 (8): 1034-47.

34. Brossier F, Veziris N, Aubry A, Jarlier V, Sougakoff W. Detection by GenoType MTBDRsl test of complex mechanisms of resistance to second-line drugs and ethambutol in multidrug-resistant Mycobacterium tuberculosis complex isolates. J Clin Microbiol, 2010; 48 (5): 1683-9.

35. Vernet G, Jay C, Rodrigue M, Troesch A. Species differentiation and antibiotic susceptibility testing with DNA microarrays. J Appl Microbiol, 2004; 96 (1): 59-68.

36. Hillemann D, Rüsh-Gerdes S, Richter E. Feasibility of the GenoType MTBDRsl assay for fluoroquinolone, amikacin-capreomycin, and ethambutol resistance testing of Mycobacterium tuberculosis strains and clinical specimens. J Clin Microbiol, 2009; 47 (6): 1767-72.

37. Walters SB, Hana BA. Testing of susceptibility of Mycobacterium tuberculosis to isoniazid and rifampin by mycobacterium growth indicator tube method. J Clin Microbiol, 1996; 34 (6): 1565-7.

38. Palomino JC, Traore H, Fissette K, Portaels F. Evaluation of Mycobacteria growth indicator tube (MGIT) for drug susceptibility testing of Mycobacterium tuberculosis. Int J Tuberc Lung Dis, 1999; 3 (4): 344-8.

39. Cheng VC, Yew WW, Yuen KY. Molecular diagnostics in tuberculosis. Eur J Clin Microbiol Infect Dis, 2005; 24 (11): 711-20.

40. Whelen AC, Felmlee TA, Hunt JM, Williams DL, Roberts GD, Stockman L, et al. Direct genotypic detection of Mycobacterium tuberculosis rifampin resistance in clinical specimens by using singletube heminested PCR. J Clin Microbiol, 1995; 33 (3): 556-61.

41. Grisold AJ, Leitner E, Mühlbauer G, Marth E, Kessler HH. Detection of methicillin-resistant Staphylococcus aureus and simultaneous confirmation by automated nucleic acid extraction and real-time PCR. J Clin Microbiol, 2002; 40 (7): 2392-7. 